Article

\title{
Teaching Industrial Ecology to Undergraduate Students: Lessons Learned
}

\author{
Changhao Liu ${ }^{1, *}$ and Raymond Côté ${ }^{2}$ \\ 1 School of Chemistry and Chemical Engineering, Beijing Institute of Technology, Beijing 100081, China \\ 2 School for Resource and Environmental Studies, Dalhousie University, Halifax, NS B3H 4R2, Canada; \\ raymond.cote@dal.ca \\ * Correspondence: changhao.liu@hotmail.com; Tel.: +86-10-8136-1383
}

Citation: Liu, C.; Côté, R. Teaching Industrial Ecology to Undergraduate Students: Lessons Learned.

Sustainability 2021, 13, 10491.

https://doi.org/10.3390/su131910491

Academic Editor: Michail

Kalogiannakis

Received: 12 August 2021

Accepted: 14 September 2021

Published: 22 September 2021

Publisher's Note: MDPI stays neutral with regard to jurisdictional claims in published maps and institutional affiliations.

Copyright: (c) 2021 by the authors. Licensee MDPI, Basel, Switzerland. This article is an open access article distributed under the terms and conditions of the Creative Commons Attribution (CC BY) license (https:// creativecommons.org/licenses/by/ $4.0 /)$.

\begin{abstract}
Industrial ecology (IE) education is a topic that has received attention in institutions of higher education throughout the world. Some universities have been teaching and researching IE for the past 20 years but its scope is still being defined. There is a need to catalog and exchange experiences of IE teaching and their results. Based on a literature review, this paper aims to provide a framework composed of content and strategies for IE teaching. This framework is tested in teaching IE as a general education course for undergraduate students at Beijing Institute of Technology (BIT). The methodology applied in this paper is of a descriptive and empirical nature and thus this paper focuses on a practice-oriented perspective in describing the experience of BIT. A range of different strategies, including lectures, group discussions, case studies, role playing games, oral presentations, evaluation, and student feedback have been incorporated in the course. The results show that the course received a highly positive evaluation by the participating students. Students were impressed by IE's characteristics of interdisciplinarity, ways of thinking, and practical value. Additionally, the course appears to influence students' values, attitudes, and behavioral intentions. The paper concludes with some thoughts on ways of improving IE education in the future.
\end{abstract}

Keywords: industrial ecology; curriculum; higher education; pedagogical approach; circular economy; China

\section{Introduction}

Education has been recognized as a vital vehicle for realizing sustainable development [1,2]. Acting as essential educational institutions, universities should be expected to play a crucial role in transforming our world toward sustainability [3,4]. Industrial ecology (IE) is arguably one of the key strategies and fields of research for achieving sustainable development especially as it relates to industrial production and consumption [5]. It is a field which balances theory and practical application [6] and thus can influence real-world activities [5]. Cockerill [1,7] argues that IE is seen as an applied approach to address sustainability from multiple perspectives. This contributes to generating "new and imaginative solutions that build on overall sustainability" [8] (p. 133). As a result of development in the past 30 years, IE has become a "noticeable presence in education" [1] (p. 78) and increasingly integrated into formal education worldwide [6]. IE education has received attention in institutions of higher education throughout the world [9,10]. It is reported that 190 universities and colleges from 46 countries were offering courses and/or programs in IE in 2012 [6]. The International Society for Industrial Ecology (ISIE) has listed IE education as one of the key topics in the field. Currently, there is a need to be aware of and exchange experiences of IE teaching and their results $[8,11]$, which will facilitate its further development. A few educators reviewed their experiences of IE education programs and courses in the past 20 years [8-10,12-20].

For instance, reflecting on their experience in teaching IE to graduate and Ph.D. students at the Norwegian University of Science and Technology (NTNU), Marstrander 
et al. [12] found that IE course helps to "recruit candidates with a more holistic understanding of the life cycle environmental performance of product systems to industry." (p. 129). Matthews et al. [16] reviewed their IE educational experience from the Green Design Apprenticeship Program of Carnegie Mellon University, which introduces graduate students with engineering interests to IE concepts. They found that it helps students to recognize the connections between engineering and environmental and social issues. Incorporating the concept of IE into undergraduate and postgraduate engineering programs at Curtin University, Biswas [19] concluded that an "IE course helps to provide a framework for incorporating relevant and impactful strategies in making engineering more sustainable" (p. 130). Sharma [17] introduced a pedagogical experiment on interdisciplinary of IE education. In this case study, the concept of IE was introduced to the discipline of landscape architecture at RMIT University. She found that a range of innovative design solutions contributing to sustainable development were generated through combining IE with landscape architecture. Cervantes [8] presented a methodology for IE teaching at the Technical University of Catalonia, in which students were able to realize the practical application of IE in the industrial field and develop their creativity to link theory to practice. The IE education in Wuhan University found that many doctoral students, mostly majoring in law, economics, policy, or engineering, were very interested in incorporating the concept of IE into their research fields [9]. Geng et al. [10] reviewed their experience of IE teaching for graduate students at Dalian University of Technology concentrating on management perspectives. This course focuses on improving the eco-efficiency of economic and social systems and facilitates to raise the students' environmental awareness in an active learning and critical reflection manner. Shi [20] reported that IE courses have become the core content in green and environmental education at Tsinghua University. He shared the experience of IE education and found that students educated in IE have been attracted to the IE research field and even graduate students from social science have been required by their research groups to attend the course [20].

Facing serious challenges of resource scarcity and environmental pollution, the Chinese government has recognized the value of IE in addressing the challenges of sustainability and has attached great importance to its philosophy. Currently, IE has been subsumed under the umbrella of the circular economy (CE) and promoted nationally [21]. CE has been positioned as a key strategy for national economic and social development by the central government of China [22]. This indicates that IE plays a crucial role for China to achieve sustainability and Chinese society will be in great need for people with the knowledge of IE. Therefore, it would appear that there is a clear need for more education on IE, especially at the university level.

University education on Industrial ecology in China began in the late 1990s [13]. Some notable universities, including Tsinghua University, Northeastern University, Wuhan University, Nankai University and Dalian University of Technology have played a leading role in promoting IE education in China. The IE educational experiences of three universities, i.e., Tsinghua University, Wuhan University, and Dalian University of Technology have been reported in the literature $[9,10,20]$. Shi [20] recently reported that more than 20 China universities are now involved in teaching IE. However, only one published paper has been found describing an approach in detail to an IE course at Dalian University of Technology [10].

Globally, although IE education at the undergraduate level is emerging, courses of IE are mainly focused on graduate level within engineering and environmental disciplines [6]. Considering the diversity of the IE field itself, the audience for IE curricula should be broader $[6,9]$. Some have argued that is necessary to expand IE education to various majors across the university $[12,17,23]$. Others have gone so far as to suggest that IE should be introduced to all students at the university in their first or second undergraduate year [12] However, IE education is a topic which has not had much discussion and debate, and there is a shortage of research done on teaching objectives and strategies for undergraduate students. More experiences on IE teaching need to be reviewed and discussed $[8,11,17]$. 
With this literature and experience in mind, this paper aims to provide a framework composed of content and strategies for IE teaching. This framework is tested in teaching IE to undergraduate students at Beijing Institute of Technology (BIT). Therefore, this paper takes a practice-oriented perspective in describing the experience of BIT. The paper is structured as follows. After this introduction, a theoretical basis for IE teaching is introduced. Then the framework is provided and has been adopted in an IE course as a general education elective curriculum opened for undergraduate students at BIT. The results of using this framework at BIT are presented and discussed. Finally, some conclusions are drawn.

\section{Theoretical Basis}

\subsection{Teaching Strategies}

Because IE education is closely related to sustainability education topics such as education for sustainable development and environmental education [7] which have been taught for a longer period of time, reviewing this literature is believed to be relevant.

Teaching for sustainability should emphasize not only obtaining cognitive learning outcomes including knowledge and understanding but also achieving affective outcomes such as values, attitudes, and behavioral intentions that stimulate creative thought [24,25]. Perdan et al. [26] argue that students' awareness of how to work and act sustainably should also be raised when teaching sustainability. Thus, a reorientation on teaching strategies is essential to achieve an effective education for sustainable development [27]. Sterling [28] stresses that a shift from mechanistic to ecological view of teaching is needed, which means a change from transmissive toward transformative learning. Figueirò and Raufflet [29] highlight the "need for a shift from a classical teaching model toward a more interactive one in which students participate in the construction of knowledge and understanding" (p. 29). Coral [27] argues that the reorientation on strategies for teaching sustainability requires ample opportunity to launch new ways of teaching, which should be more centered on students [2,30-32]. Most authors argue that adopting a wide range of teaching strategies is essential for teaching sustainability [27,28,33-35]. Respecting a variety of different approaches toward education for sustainable development is considered to be the best way forward and is believed to be at the philosophical heart of sustainability [27]. Perdan et al. [26] adopt lecture sessions, small-group discussions, case studies and role-plays in their sustainable development education programmes. Widener et al. [36] found that adopting different teaching strategies including lecture, discussion, and a group project can help students to understand sustainability with various approaches. Cotton et al. [31] found that pedagogies such as discussion, role play and case studies are viewed as very appropriate methods for education for sustainable development by respondents from in-depth interviews. Piasentin and Roberts [35] adopted a range of teaching strategies, composed of lectures interspersed with other strategies such as video clips, class discussions, required and optional readings, student presentations, a structured debate, field visit, pre- and post-course questionnaires, and feedback in a sustainability course, in an effort to facilitate paradigm change for university students. Figueirò and Raufflet [29] argue that the action learning method, which adopts tools such as case studies, teamwork, projects, games, and discussions, provides a promising approach for teaching sustainability. With the aim of generating cognitive engagement, it can "increase students" motivation and develop their critical thinking skills" [29] (p. 28). Christie et al. [34] found that academics are actively seeking to make their courses more interactive and prefer to adopt a range of strategies including lectures, tutorials, critical thinking and discussions in their teaching on sustainability.

Among the teaching strategies of sustainability, questionnaires have often been adopted to understand students' understanding, awareness, and attitudes [37,38]. Lecturing is considered to be the most widely used teaching strategy at universities $[27,34]$, which works well for acquiring factual information $[1,34,39]$. When teaching sustainability, it is important to introduce students to underlying concepts $[27,40]$. However, lecturing is often 
perceived as a passive method and focuses on a one way delivery of information [33,34,41]. Teaching sustainability only by lecturing is not very effective $[27,42]$. When integrated with other teaching strategies, it can be more effective [27,34].

Case studies have been successfully adopted to teach courses on sustainability $[43,44]$. They can be used to explore specific issues such as examples of actual practice [27], which assists in reflecting on real-world problems $[27,43,45,46]$. Thus, it is considered to be particularly well suited to teach sustainability and should be generally included in strategies for teaching sustainability $[43,47]$. Group discussions is frequently adopted as an effective teaching strategy for sustainability $[33,34,48]$, which can help students to have a deeper understanding of the topic of sustainability [49]. It facilitates the mutual learning and generation of effective interaction among students with difference backgrounds [50,51]. The role play is an excellent teaching strategy to "understand and to work with" reality and should be added to courses in sustainable development education [52]. It can contribute to simulating the real world [53] and helping students to acquire a systemic way of thinking [27,52] and "effect shifts in their personal paradigms, context and practice that are needed for sustainable development" [52] (p. 837). Strengthening connections between the role play and other teaching strategies, such as lectures and student assignments can provide more effective learning on sustainability [54]. Through introducing the role play to class, students can obtain opportunity to deeply understand and empathize with others [34], and achieve cognitive and affective learning outcomes in an effective way [25].

Assessment on students' performance has been considered to be a complex task [55]. Because using a singular assessment often causes deviations, a diversified evaluation approach should be adopted for teaching sustainability [51,56]. It is considered that assessment ought to be perceived as a "two-way process of interaction between educator and learner" and thus students can be generally evaluated "according to criteria such as: activity in groups, individual work, and their final report" [55] (p. 251). Because good teaching is often interactive and dialogic, feedback should be incorporated into the teaching strategies of sustainability [57]. It motivates students to ponder over their own values, beliefs and attitudes [35] and is helpful for teachers to know students' perception of their learning [55]. In this way, educational deficiencies can be uncovered and the positive aspects of the course can be highlighted [58]. Thus, feedback plays an essential role in the continuous improvement of the course [58,59].

As for IE teaching, methods frequently used mainly involve lectures $[8-10,12,17,19,20]$, group discussions $[8,10,12,17,20]$ and case studies $[10,12,16,19,20]$. As a teaching aid, field investigations are also found to be employed $[7,10,20]$ and identified as one of the most interesting and worthwhile experiences for students in IE education $[18,20]$. However, it often faces challenges such as geographical location, time constraints, safety or privacy concerns on the part of companies, and limitation of financial support $[18,20]$, especially for teaching at undergraduate level [20]. Second life, which is a virtual learning tool, has been introduced in IE teaching at Yale University and is suggested to be a supplement to conventional tours [18]. Role play has still not been fully used and only one paper is found to introduce it in teaching IE to graduate and Ph.D. students [12]. In general, the current methods of teaching IE reflects a combination of passive learning and active learning. Although some of teaching methods have been included in IE education, integrating a wide range of strategies needs to be adopted, especially at the undergraduate level.

\subsection{Teaching Content}

Currently, the content of IE education presented in the education-based literature includes: concepts and history of IE [8-10,20], life cycle assessment (LCA) and management $[9,10,12,17,19,20]$, substance flow analysis (SFA) [20], material flow analysis (MFA) [9,12,20], industrial metabolism [12], environmental input-output analysis [20,60], design for environment $[9,10,17,20]$, extended producer responsibility $[9,12]$, green and sustainable engineering $[12,16,19]$, cleaner production $[10,12,19,20]$, eco-efficiency strategies [12,19], industrial symbiosis (IS) and eco-industrial parks $[8-10,17,19,20]$, green chem- 
istry [19], environmental policy [9], circular economy [10], sustainable consumption [10], and integrated waste management [10]. Among these topics, industrial symbiosis, ecoindustrial parks and life cycle analysis are the most common topics $[7,17,20]$. Material flow analysis (MFA), life cycle analysis (LCA), and design for environment are often considered to be some of the fundamental methods that comprise the IE toolbox $[17,20]$. Some IE related course addresses larger IE ideas which focus on separate topics including life cycles, energy, water, transportation, built infrastructure, and life cycle decision making [16]. In addition, it is found that some interesting topics related to IE have been incorporated into IE curriculum, such as biomimicry [19] and green building [16,17].

Some authors reflect on the content of IE curriculum and put forward some suggestions. Shi [20] argues that it is often difficult to design up-to-date IE curriculum modules because the IE field is still evolving. Marstrander et al. [12] suggest that designers of IE courses noted that the lecturer needed to consider whether they were educating generalists or specialists. Geng et al. [10] consider that combining knowledge of IE with local realities is one of the most important points for improving the quality of IE education.

\section{Methodology}

With this in mind, the methodology applied in this paper is of a descriptive and empirical nature. A framework for teaching IE as a general education course for undergraduate students has been established. The framework is composed of a range of teaching strategies integrated and teaching contents appropriate to IE, which has been applied to IE teaching at BIT since 2016. The last time this course was taught for the purposes of the data in this paper is the fall semester of 2019. Using this framework, we uncovered how IE teaching can be developed at the undergraduate level in an effective way. Preand post-course questionnaires, which is one of the strategies included in the framework, is qualitatively used to collect information and analyze for the research. The students were required to complete the pre- and post-course questionnaires at the beginning and end of the course respectively. The pre-course questionnaire aims to appreciate the background of students' understanding on the concept of IE and other related concepts. The post-course questionnaire seeks to gather the information of students' feedback on their personal perceptions of the experience on IE education. Both of the questionnaires were collected in the classroom. The study was carried out during the 2016-2019 academic year. 246 undergraduate students selected the course. The gender distribution was $66 \%$ of male and $34 \%$ of female. A total of 243 students participated in the pre-survey and 218 students participated in the post-survey from 2016 to 2019. Response rates were $97 \%$ on the pre-survey and $89 \%$ on the post-survey.

\section{Background Information of IE Education at BIT}

Established in 1940, BIT is a university of science and engineering with a student population of about 30,000 . It has been one of the key universities given priorities from Chinese government and is now affiliated with the Ministry of Industry and Information Technology (MIIT). The Chinese government embraced the concept of circular economy in 2002 as a new development strategy which aims to achieve a harmonious development between economy and environment [61]. The concepts of IE were positioned as a key aspect supporting circular economy and applied at a jurisdictional and geographic level [21] Based on this context, BIT believes IE is an emerging and promising discipline for China to eliminate the apparent contradiction between economy and environment. To promote the development of research and education on IE, BIT chose the School of Chemical Engineering and the Environment, and incorporated an Eco-industry Research Center in 2003. Teachers of this research center were graduated from the IE field and are the first group of students graduated from the IE program in China. They have engaged in IE research such as developing the Chinese national demonstration area plan for eco-industrial parks and investigated several well-known IE cases of China. This helps to lay a discipline knowledge background foundation for IE teaching in BIT. From 2005 to 2015, IE had been 
taught to graduate students as a specialized elective course for majors in environment at the School of Chemical Engineering and the Environment. The IE course received positive feedback from students. In 2016, in order to highlight dominant disciplines, BIT combined chemical engineering and chemistry to establish a School of Chemistry and Chemical Engineering and cancelled the major of environment. The IE course for graduate students was dropped because of this adjustment of disciplines. However, in order to broaden students' horizons and knowledge, BIT greatly encourages teachers to offer general education electives for undergraduate students at the whole university level, especially the courses that can help students to develop innovative ways of thinking and is of important practical significance. Considering the important value of IE and its crucial role for implementing China's ecological civilization strategy development in recent years [21], BIT believes IE needs to be educated by undergraduate students of various majors and approved IE as a general education elective for undergraduate students. The course aims to help students build a new way of thinking through the lens of IE, lay a knowledge base for potential combination of IE with their majors and encourage them to integrate IE into their decision making in the future.

Up to the fall semester of 2019, a total of 246 undergraduate students were trained since the course was initiated in 2016 and the course was offered five times. Students can take part in the course in any of the four years of their bachelors' programs. More than $90 \%$ of students joined the course in their first or second undergraduate year because they tend to complete their general education elective courses in their first two years. Students can obtain two credits from the course. Students who chose this course are from 31 majors in 15 schools, which covers engineering disciplines with 79.3\%, humanities and social sciences with $12.6 \%$, and natural science with $8.1 \%$. Many of the students are from majors such as electronic information $(12.9 \%)$, vehicle engineering $(10.2 \%)$, material science $(9.7 \%)$, chemical engineering $(8.1 \%)$, mechanical engineering $(6.1 \%)$, software engineering $(5.3 \%)$, and automation $(4.8 \%)$.

\section{Framework of Teaching IE as a General Education Course for Undergraduate Students at BIT}

Given the literature review above, the framework of IE teaching for undergraduate students presented in this paper is composed of content and strategies, which is shown in Figure 1. According to the IE education literature, designing the main teaching content of the course is considered from the following four aspects: (1) the most common topics on IE, including industrial symbiosis and eco-industrial parks $[7,17,20],(2)$ the fundamental tools of IE, such as material flow analysis (MFA), life cycle analysis (LCA), and design for environment $[17,20],(3)$ topics that have been addressed in recent years in the field, such as the concept of ecosystem services [21,62], and (4) other topics related to IE, such as the circular economy. In addition, as a general education course for undergraduate students, in order to raise students' interest and help them better understand the practical application of IE in the real world for promoting sustainable development, relevant cases are selected for special attention. These contents are highly relevant with sustainable development.

As for teaching strategies, a wide range of different strategies are tested in the course, combining passive and active learning. These strategies have been proved to be effective for teaching sustainability through the literature review. The frequently used strategies of IE teaching, such as lectures $[8-10,12,17,19,20]$, group discussions $[8,10,12,17,20]$, and case studies $[10,12,16,19,20]$ have been incorporated in the course. Identified as a very promising approach for teaching sustainability, role playing games is considered to be connected to other teaching strategies [54] and has still not been reported to be used for IE teaching at the undergraduate level. Therefore, it is incorporated into the teaching strategies of this course. In addition, this course embraces other strategies including a questionnaire of students' understanding on IE at the beginning of the course, oral presentations, and student feedback. 


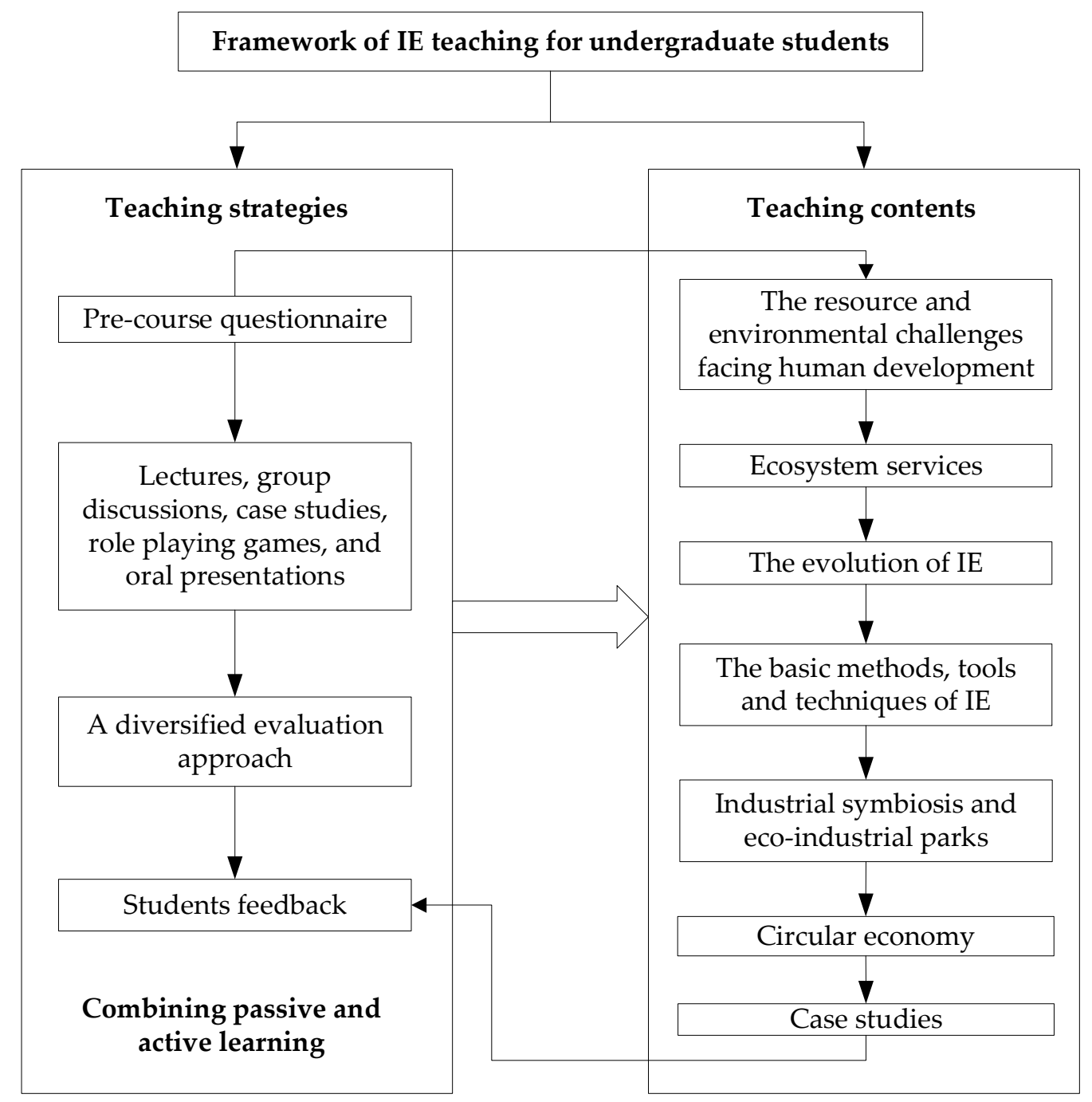

Figure 1. Framework of IE teaching for undergraduate students.

\subsection{The Content of the Course}

The course is set at 32 credit hours, which involves $28 \mathrm{~h}$ for lecturing and group discussion, $2 \mathrm{~h}$ for role playing games, and $2 \mathrm{~h}$ for oral presentation. The course is composed of seven parts and the main contents and related descriptions are shown in Appendix A (Table A1).

\subsubsection{Part One}

Part one introduces the resource and environmental challenges facing human development, which aims to make students realize it is urgent for humanity to adopt a creative approach to achieve the goal of sustainability. Integrating local realities into IE teaching plays an important role in improving the outcomes of teaching [10]. Therefore, China's current status of resource scarcity and environmental pollution is specifically emphasized in order to help students recognize the necessity and significance of developing IE in China.

\subsubsection{Part Two}

Combining the concept of ecosystem services with IE has recently gained prominence by researchers and practitioners in the IE field [21,62]. This course incorporates the concept of ecosystem services, which helps to reflect the progress in the IE field. This content has not been reported in other IE education literature. In this part, the basic concept and structure of natural ecosystems is presented. Then based on the reports of the United Nations Millen- 
nium Ecosystem Assessment (see http:/ / www.unep.org/maweb/en/Index.aspx, accessed on 5 June 2019), the concept of ecosystem services and current state of global ecosystem services is introduced. This enlightens students to deeply understand the value of ecosystem services. To make students reflect on what is the relationship between ecosystem services and sustainable development, this part introduces the 17 Sustainable Development Goals that combine economic, social, and ecological dimensions put forward by the UN 2030 Agenda for Sustainable Development [63]. To highlight the significance of ecosystem services for China, the current situation of China's ecosystem services and the relationship between ecosystem services and China's Ecological Civilization are emphasized for students as well. The report published by UNEP [64], "Green is Gold: The Strategy and Actions of China's Ecological Civilization", the United Nations Millennium Ecosystem Assessment reports, as well as the UN 2030 Agenda for Sustainable Development are suggested as reading materials for students.

To make students understand the practical application related to ecosystem services, the concept and cases of green infrastructure are presented. Students are assigned to search for some cases of green infrastructure and encouraged to present the cases orally in class.

The learning of this part helps students to realize that economies are bounded by ecosystems. This can lay a foundation for exploring whether industry can adapt and replace ecosystem services.

\subsubsection{Part Three}

Part three presents the concepts and evolution of IE. Different approaches to environmental management, including end-of-pipe treatment, cleaner production, eco-efficiency and IE are introduced. Then, different definitions of IE and its evolution are presented and examined. The characteristics and significance of IE research is also introduced. To help students better understand the connotation of IE, the seminal article in the IE field, "Strategies for Manufacturing" written by Frosch and Gallopoulos [65] is provided to students as an important reading material. Students are guided to make an analogy between natural ecosystems and industrial ecosystems. Students then reflect on the differences and discuss the relationship between cleaner production, eco-efficiency and IE in order to comprehend the role and scope of IE.

\subsubsection{Part Four}

Part four focuses on the basic methods, tools and techniques of IE. The methods mainly involve material flow analysis (MFA), life cycle assessment (LCA) and design for environment (DFA). Some researchers found that it is more important to have students comprehend the theories supporting these methods, rather than technical skills to use these methods [12]. So we emphasized to educate students to understand the concepts, principles and roles of these qualitative methods. Cases of using these methods are introduced in order to help students understand the role of practical application of the methods. Extended producer responsibility (EPR) is also an important content of IE education [9,12]. In China, it has been incorporated into the Circular Economy Promotion Law of China and is being implemented by the government as one of the key policies supporting the circular economy. For this reason, EPR is emphasized in this part. The concept, history and application of EPR is introduced. China's Extended Producer Responsibility Plan, which was issued by the State Council in 2017 and aims at guiding the implementation of China's EPR, is specifically explained.

\subsubsection{Part Five}

Industrial symbiosis and eco-industrial parks, which are both key sub-fields of IE $[5,66]$ and considered to be the most common topics on IE education $[7,17,20]$, are explained in detail in the course. The definitions of industrial symbiosis and eco-industrial parks are introduced to students. Then a detailed description and explanation of the famous regional industrial symbiosis of Kalundborg, Denmark is undertaken. To make students 
fully comprehend the operation of industrial symbiosis in practice, students are required to think about and discuss the drivers and barriers for industrial symbiosis. Students are also encouraged to identify the potential industrial symbiotic opportunities in their hometowns and give their oral presentations in class.

According to the United Nations Environment Programme (UNEP), industrial parks have been a common characteristic in the global landscape [67] and are playing a significant role in China's economic development [21]. To strengthen the environmental management for industrial parks, China has vigorously promoted the construction of eco-industrial parks. The background information of China's eco-industrial parks is introduced to students. In this part, students are further guided to reflect on what a real eco-industrial park should be. In addition to the establishment of industrial symbiotic relationships, what other considerations should be addressed. The concept of ecosystem services, which has been introduced in part two, is connected to eco-industrial parks in this part. The viewpoint of integrating the concept of ecosystem services into industrial parks [61] is explained to students. Then the principles and practices of designing eco-industrial parks, which are important contents for IE education [68], are emphasized to students. Related policies on promoting the development of eco-industrial parks in China are also introduced. Some papers on definitions and experiences on industrial symbiosis and eco-industrial parks written by Chertow [69], and Côté and Cohen-Rosenthal [5], which have been widely cited in the IE field, are provided to students as reading materials in this part.

\subsubsection{Part Six}

Part six focuses on the circular economy. The different concepts and principles (reduce, reuse and recycle) of circular economy are introduced. The two cycles, i.e., technical cycle and biological cycle, put forward by the Ellen MacArthur Foundation (See https: //www.ellenmacarthurfoundation.org/, accessed on 6 June 2019), which is playing an active role in globalizing the concept of circular economy, is specifically emphasized in order to help students better comprehend the underpinnings of circular economy. Positioned as a key strategy for China's development, many measures have been taken to promote its development. Therefore, the background, history and practice on circular economy in China is presented emphasizing the policy on circular economy, which has played an essential role in guiding the development of circular economy in China.

The professor emphasizes to students in this part that circular economy practice specifically needs to include restoration and regeneration of ecosystem services, especially for China facing the challenges of losing many valuable services. Therefore, encouraging the development of scavenger and decomposer companies in the economic system [70-72] is particularly important for establishment of a circular economy system. Some examples are introduced to students such as companies who exploit urban mining [73,74]. The Circular Economy Promotion Law [22], which lays a legal foundation for China's circular economy, is also introduced. Students are guided to further reflect on the relationship between IE and circular economy in order to better understand the two concepts. In this part, the report of Ellen MacArthur Foundation [75] are suggested to students as reading material.

\subsubsection{Part Seven}

The importance of including more realistic problems should be emphasized when teaching sustainability in the classroom $[29,76]$. In view of the highly variable and practical nature of IE [5], part seven focuses on case studies, which aims at addressing a real-world problem and helping students better understand the application of the main knowledge in practice from more examples.

This part is composed of cases from three levels, i.e., individual firm level, industrial park level and social level. The cases of individual firm level mainly focus on companies that achieve a win-win situation between economy and environment through implementing cleaner production. Some eco-designed products are also introduced. At the industrial 
park level, the Burnside Industrial Park of Canada, the Devens eco-industrial park of the United States, the Tianjin Economic-Technological Development Area (TEDA) of China, and the Hai Hua Industrial Symbiosis of China are presented, focusing on the industrial symbiotic relationships and especially the role played by scavenger and decomposer companies [72] in these industrial parks. Furthermore, the practice on protecting and restoring ecosystems services of these industrial parks is specifically emphasized, helping students further understand the link between the concept of ecosystem services and IE and how to incorporate the concept of ecosystem services into construction of ecoindustrial parks.

Cases from the social level focus on the key fields of implementing IE and circular economy in China. Garbage classification is a very realistic problem for China and being greatly promoted. Students are guided to reflect on the role and significance of garbage classification from the perspective of the technical and biological cycles put forward by the Ellen MacArthur Foundation. Electrical and electronic products have been chosen as pilot area for implementing extended producer responsibility in China. Cases of related projects are presented. In addition, examples of green consumption are also introduced. The purpose of case studies at the social level is also to help students realize that the participation of governments, companies, citizens as well as other related organizations is essential for implementing IE and circular economy at this level.

In addition to the reading materials provided to students mentioned in above sections, the Chinese edition of the well-known university textbook, Industrial Ecology, written by T. E. Graedel and B. R. Allenby [77], and translated by Han Shi, is suggested to students as the textbook for the course.

\subsection{The Teaching Strategies of the Curriculum}

To appreciate the background of students' understanding on the concept of IE and other related concepts, a questionnaire was developed at the beginning of the first lesson. Questions such as: (1) Are you aware of sustainability or sustainable development? (2) If yes, please provide some words to describe it. (3) Are you aware of IE? (4) If yes, where did you hear of it- the Internet, news media, other courses, other sources? (5) If from previous courses, what are the names? (6) What is your understanding of IE?

In addition to adopting lectures on introducing concepts and basic methods and tools, case study is extensively used to help students explore and understand how the knowledge is applied and plays a role in the real world. A multidisciplinary approach needs to be addressed for IE education $[1,10,12,20]$. Therefore, we emphasize to guide students to understand the cases from multiple perspectives including technical, economic, and social, which helps students to comprehensively and deeply understand the cases. Based on the understanding of the cases, we further encouraged them to try to put the knowledge into practice in the future, such as designing a product combining with the two cycles of circular economy, exploring opportunities of establishing green infrastructure and industrial symbiosis in university campus or their hometowns. To make students better feel and observe the cases, some interesting video clips and pictures, many of which were collected by the course teacher when conducting field investigations, were displayed in class.

Group discussions aim to encourage students to express and share their own viewpoints. When conducting group discussions, we tried to divide students into groups composed of different majors in order to help students to expand thinking from different perspectives.

A role playing exercise aims to assist students in gaining a better appreciation of an industrial ecosystem and understand the different roles involved in implementing an industrial ecosystem was developed. The role playing game is designed as having two parts: (1) Mimic the process of establishing industrial symbiotic relationships between two companies. Six to twelve students are divided into two groups. Each group can be composed of people from different departments of a company, such as management, technology, finance, security, environmental protection and production workshop. Students are required to express their opinions from the perspective of people from the above mentioned 
departments. In addition, students are also guided to reflect on drivers and barriers from aspects such as resource and environmental problems that the company is facing, policies from the government, and adjacent communities when establishing industrial symbiotic relationships between two companies during this process. (2) Students are required to reflect on the reason for implementing IE and how to implement IE by playing roles of different stakeholders, including company leaders, government officials and general public. Students will be the future leaders of companies and governments. Through this part of role play, they can experience how different stakeholders can incorporate IE into their decision making. Nonplayers are given observational and reflective tasks and can express their opinions during the process of the role play.

Oral and power point presentations by students are encouraged during the process of giving lectures. Students can choose topics such as: (1) analyzing a case of green infrastructure, (2) identifying the potential industrial symbiotic opportunities in their hometowns, and (3) analyzing a case of extended producer responsibility.

A diversified evaluation approach which is based on regular performance and a final report for the course is adopted. The regular performance encompasses activity in groups, homework, oral presentation and role playing games, which account for $40 \%$ of the grade. Oral presentation and role playing games are two voluntary parts for students and students can obtain extra points. The final report for the course accounts for $60 \%$ of the grade and aims to evaluate the students' understanding of concepts and ability of thinking and solving practical problems through applying the knowledge from the course. Some topics provided to students mainly involve: (1) analyzing or designing an industrial symbiosis or eco-industrial park through applying the knowledge from the course, and (2) applying the knowledge from the course to guide the urbanization process. Considering the students are more familiar with their hometowns, they are encouraged to finish the final report based on the context of their hometowns.

At the end of the course, the information from students' feedback on IE education is gathered through an anonymous questionnaire conducted to understand students' personal perceptions of the experience in order to improve the course in the future.

\section{Results and Discussion}

\subsection{Students' Understanding on the Concept of IE at the Beginning of the Class}

All the students who chose the course participated in the questionnaire at the beginning of the class. The results are shown in Table 1. It can be seen that although China is now facing challenges to sustainable development, $31.69 \%$ of the students who only heard of sustainability or sustainable development and did not know what sustainability or sustainable development means. Compared with the concept of sustainable development, students were more unfamiliar with IE at the beginning of the class. Of the students, $44.44 \%$ who chose the course never heard of IE and $55.14 \%$ of them only heard of it. This implies that introductory education on IE is essential to many students. Only one student understood IE well. The reason is that his father, who works at an industrial park implementing IE, often talks about something related to IE with him. Among the students who had only heard of IE, surprisingly, $42.39 \%$ of them heard of it from other courses including biology, geography, and chemistry, during their high school studies. It is interesting to find that some high school courses in China have mentioned the word "industrial ecology". This has not been reported by other authors and is surprising. In addition, the findings of our study reveal that in general, the percentage results of female students are more positive than that of males. This observation confirms the findings of other researchers that female students are likely to be more concerned about environment-related issues compared to males [78-80]. 
Table 1. A questionnaire survey on students' understanding on the concept of IE at the beginning of the class.

\begin{tabular}{|c|c|c|}
\hline & Questions & Results \\
\hline 1 & $\begin{array}{l}\text { Are you aware of sustainability or } \\
\text { sustainable development? }\end{array}$ & $\begin{array}{l}\text { - } \quad \text { Never heard of them: } 1.23 \% \text { (Male: } 1.88 \% \text {, Female: } 0.00 \% \text { ) } \\
\text { - } \quad \text { Only heard of them: } 31.69 \% \text { (Male: } 34.38 \% \text {, Female: } 26.51 \% \text { ) } \\
\text { - } \quad \text { Know a little about them: } 52.26 \% \text { (Male: } 51.25 \% \text {, Female: } 54.22 \% \text { ) } \\
\text { - } \quad \text { Understand them well: } 14.81 \% \text { (Male: } 12.50 \% \text {, Female: } 19.28 \% \text { ) }\end{array}$ \\
\hline 2 & $\begin{array}{l}\text { If yes, please provide some words } \\
\text { to describe it. }\end{array}$ & $\begin{array}{l}\text { - Words provided mainly involve: } \\
\text { Stable, balance, recycle, high efficiency, environment-friendly, no waste, no } \\
\text { pollution, green, clean, low carbon, creative, regenerate, permanent, new energy, } \\
\text { benefit future generations, and protecting ecosystems }\end{array}$ \\
\hline 3 & Are you aware of IE? & $\begin{array}{ll}\text { - } & \text { Never heard of it: } 44.44 \% \text { (Male: } 46.88 \% \text {, Female: } 39.76 \% \text { ) } \\
\text { - } & \text { Only heard of it: } 55.14 \% \text { (Male: } 52.50 \% \text {, Female: } 60.24 \% \text { ) } \\
\text { - } & \text { Know a little about it: } 0.00 \% \text { (Male: } 0.00 \% \text {, Female: } 0.00 \% \text { ) } \\
\text { - }\end{array}$ \\
\hline 4 & $\begin{array}{l}\text { If yes, where did you hear of IE-the } \\
\text { Internet, news media, other courses, } \\
\text { other sources? }\end{array}$ & $\begin{array}{l}\text { - TV news or documentary: } 56.79 \% \text {, } \\
\text { - } \quad \text { Other courses: } 42.39 \% \text {, } \\
\text { - } \quad \text { Readinet: } 37.03 \% \text {, books: } 32.51 \%, \\
\text { - } \quad \text { Other sources: } 12.35 \%\end{array}$ \\
\hline 5 & $\begin{array}{l}\text { If from previous courses, what are } \\
\text { the names? }\end{array}$ & $\begin{array}{ll}\text { - } & \text { Biology, } \\
\text { - } & \text { Geography, } \\
\text { - } & \text { Chemistry }\end{array}$ \\
\hline 6 & What is your understanding of IE? & $\begin{array}{l}\text { - "Develop the industry which is beneficial to ecology", } \\
\text { - "A green industry based on the principle of ecological balance", } \\
\text { - "A new manufacturing mode which aims to protect the environment", } \\
\text { - "Reflect on the development of industry from the perspective of ecology", } \\
\text { - "Helpful for realizing the harmony between human and nature", } \\
\text { - "Meet with the rule of natural ecosystem", } \\
\text { - "Industry should be formed in an interconnected system similar to the } \\
\text { natural ecosystem" }\end{array}$ \\
\hline
\end{tabular}

Students provided their viewpoints on IE at the beginning of the class including some interesting opinions such as "industry should be formed in an interconnected system similar to the natural ecosystem", "a green industry based on the principle of ecological balance", and "meet with the rule of natural ecosystem".

\subsection{Role Playing Games Played an Important Role in the Course}

The role playing exercise can allow students to visualize the real world while making decisions when implementing IE [12]. In our course, students are introduced to implementing IE by playing roles of different stakeholders are shown in Table 2. Many students chose the role of company leaders because they thought companies are the main body in real economic activities, which therefore should also be the main body for implementing IE. They argued that profit is a key factor for companies to implement IE because the main purpose for a company is to achieve profits. Otherwise, companies will lack motivation for implementing IE. Students also felt that there are many other reasons for companies to develop IE, such as pressures for environmental protection, social responsibility, and green image. From Table 2, it reveals that students identified many aspects on implementing IE and students who played a role of company leaders, government officials and general public all considered that developing education on IE is very essential for implementing sustainable development. Therefore, through this part of the role play exercise, student more deeply appreciated that many stakeholders should and could play important roles in promoting the development of IE at the social level. 
Table 2. Students' viewpoints on implementing IE by playing roles of different stakeholders.

\begin{tabular}{|c|c|c|}
\hline $\begin{array}{c}\text { Playing Roles of Different } \\
\text { Stakeholders }\end{array}$ & Reason for Implement IE & How to Implement IE \\
\hline Company leaders & $\begin{array}{l}\text { - } \quad \text { Achieve economic benefits, } \\
\text { - } \quad \text { pace pressures from environmental } \\
\text { - Helpful for enhancing } \\
\text { - } \quad \text { Dempetitiveness } \\
\text { - } \quad \begin{array}{l}\text { Helpful for establishing a green } \\
\text { image }\end{array}\end{array}$ & $\begin{array}{l}\text { - Understand IE, especially the benefits from } \\
\text { implementing IE, } \\
\text { - } \quad \text { Learn from the experience of other companies } \\
\text { implementing IE, } \\
\text { - } \text { Understand relevant policies issued by } \\
\text { governments on implementing IE, } \\
\text { - } \quad \text { Educouraged and guided by government, } \\
\text { - } \quad \text { Incorporate IE into corporate culture, } \\
\text { - Get enough information which can be used to } \\
\text { establish industrial symbiotic relationships } \\
\text { - } \quad \text { Gith other companies, } \\
\text { ret technical support from government or } \\
\text { related organizations }\end{array}$ \\
\hline Government officials & $\begin{array}{l}\text { - } \quad \text { International attention on IE } \\
\text { an effective path for China to } \\
\text { achieve ecological civilization and } \\
\text { sustainable development } \\
\text { - Great importance attached by the } \\
\text { government on IE } \\
\text { Increase of the environmental } \\
\text { protection consciousness of citizen }\end{array}$ & $\begin{array}{l}\text { - } \quad \text { Carry out education and training } \\
\text { - } \quad \text { Promulgate laws, regulations and policies } \\
\text { - } \quad \text { and the media } \\
\text { - Summarize and promote experience of } \\
\text { implementing IE } \\
\text { - } \quad \text { Develop international cooperation } \\
\text { Establish specific government departments } \\
\text { responsible for promoting IE }\end{array}$ \\
\hline General public & $\begin{array}{l}\text { - Increasingly serious environmental } \\
\text { and ecological problems, which } \\
\text { threatens people's health } \\
\text { - } \quad \text { Citizen's responsibility } \\
\text { - } \quad \text { Responsible for future generations }\end{array}$ & $\begin{array}{ll}\text { - } & \text { Receive education and information on IE } \\
\text { - } & \text { Carry on green consumption } \\
\text { - } & \text { Participate in organizations related with IE and } \\
& \text { put forward suggestions on implementing IE }\end{array}$ \\
\hline
\end{tabular}

Through students' role playing in establishing industrial symbiotic relationships between two companies, they begin to understand that companies could benefit because they can deal with resources and environmental problems. Students felt that many factors need to be considered when establishing industrial symbiotic relationships, which makes the establishment and evolution of an IS challenging. For example, students proposed that agreements on protecting the important information such as production cost and techniques must be signed between the two companies before establishing industrial symbiotic relationships. It will be easier to establish industrial symbiotic relationships if byproducts from one company can be directly used by another company. However, if investments are needed, such as laying pipes for transferring steam, companies will negotiate on how to invest in such projects, which could be time-consuming. Students also stressed that companies will want to confirm whether using a waste from another company is permitted by law or government. They further felt that "a short mental distance" [81] and trust are indeed very important for companies aiming at establishing symbiotic relationships. Therefore, it shows that the role playing exercise helps students to deeply understand the knowledge and experience how to make decisions through the lens of IE in the actual real world.

In sustainability education, the role play is perceived as a support tool for improving group communication [82]. In our study, two student groups acted as two individual companies for establishing a symbiotic relationship. In each group, students who were from different majors acted as people from different departments of a company. When mimicking the process of establishing symbiotic relationships between these two companies, these 
students expressed their opinions from many different perspectives. This makes them very interested in discussing and communicating extensively with others on how to establish a symbiotic relationship. When playing the roles of different stakeholders of implementing IE at the social level, it reveals that students were very interested in sharing their opinions with others who selected the same roles, discussing with them and then summarizing their viewpoints. Therefore, it confirms the point of view of Camargo et al. [82] and demonstrates that the role play exercise is a very effective way to improve the communication among students for IE teaching.

It also shows that the role playing game helps students to actively apply the knowledge gained in the course. For example, in order to conduct the role playing game on establishing symbiotic relationships, students actively reviewed some related knowledge such as the concept, characteristics and roles of industrial symbiosis, and drivers and barriers for establishing an industrial symbiosis in advance using their time after class. They also searched and read more information about some examples of industrial symbiosis. This makes them better understand the knowledge of the course and how it can be applied in the real world after the game. This role of active learning is also emphasized by other researchers [83-85].

\subsection{Students' Feedback on the Course}

When the course ended, students provided feedback on the course through an anonymous questionnaire which is composed of some open-ended questions. Representative content of students' feedback are listed in Table 3. All quotes are derived from the students' anonymous questionnaires. It shows that the majority of them were attracted by the concept. The reasons provided by the students can be mainly summarized in four categories as follows: (1) IE underscores the importance of interdisciplinarity and for many students, a new way of thinking, especially system thinking. (2) The knowledge imparted in the course is fresh and is their first introduction to the subject matter. (3) IE is a relevant choice in this era of sustainability with great potential for a better approach to industrial development. (4) As taught, IE engages students in both theory and practice especially in a technology focused university. It appears that students are impressed by IE's characteristic of interdisciplinarity, way of thinking and practical value.

Students are very interested in the analogy between ecosystems and industrial systems. They noted that it is necessary for human to learn more from natural ecosystem and follow the law of nature. The Kalundborg industrial symbiosis held the most interest among the various cases. Its evolutionary process is considered to be almost magical by students. It is interesting to find that some student stated that "Industrial symbiosis assists in inspiring people to discover connections between things in life and understand that win-win cooperation is a fundamental solution to problems".

Many students were intrigued by the role playing. For example, one student noted, "The role play exercise gives me a sense of accomplishment and helps me to deeply understand the knowledge". Another student wrote, "The role playing games makes me generate thoughts that are closer to reality and exercises my ability to express myself and communicate with others". In general, it is obvious that many students considered that role playing games a very interesting, active, and novel learning approach and helpful for them to think from different stakeholders' perspectives in practice. This observation is similar to the experience of sustainability education described by McConville et al. [54]. The findings from the students' feedback further demonstrated the role and value of role playing games which is discussed in Section 5.2. 
Table 3. Students' feedback on IE education.

\begin{tabular}{|c|c|c|}
\hline & Questions & Results \\
\hline 1 & Are you attracted by IE? Why? & $\begin{array}{l}\text { Almost all the students were attracted by IE. } \\
\text { Reason examples: } \\
\text { - "IE is very innovative and provides a completely new way of thinking and } \\
\text { many concepts which I never heard of before" } \\
\text { - "The natural ecosystem is very worth us to learn" } \\
\text { - "Very new idea which is close to life and is applicable to everyday life", } \\
\text { - "Cross disciplines between natural science and social science and very } \\
\text { - "Reaningful", } \\
\text { - "A subject a combination of high-tech and humanities", } \\
\text { - "Drive us to pay attention to ecology and strengthen our responsibility" } \\
\text { - "Essential for the development of human society, especially for China to } \\
\text { establish ecological civilization and achieve sustainable development" }\end{array}$ \\
\hline 2 & $\begin{array}{l}\text { Which content are you most } \\
\text { impressed by during this } \\
\text { course? }\end{array}$ & $\begin{array}{l}\text { - "The idea of IE", } \\
\text { - "Analogy between natural ecosystem and industrial system", } \\
\text { - "The function of ecosystem services", } \\
\text { - "The concept of green infrastructure and its application in practice" } \\
\text { - "The role of industrial symbiosis" } \\
\text { - "Cases of industrial symbiosis and eco-industrial park", } \\
\text { - "The evolution of Kalundborg industrial symbiosis" } \\
\text { - "The technical cycle and biological cycle of circular economy" } \\
\text { - "Role playing games", } \\
\text { - "Identify the potential industrial symbiotic opportunities for hometowns" }\end{array}$ \\
\hline 3 & Suggestions on this course? & $\begin{array}{l}\text { - "All of the college students need to be trained on IE", } \\
\text { - "Field trip and survey on an industrial symbiosis", } \\
\text { - "Introduce more cases on industrial symbiosis and eco-industrial park", } \\
\text { - "More time for oral presentation and role playing games", } \\
\text { - "Debate can be added", } \\
\text { - "Discuss on how to improve an operating industrial symbiosis" }\end{array}$ \\
\hline
\end{tabular}

Students are also interested in identifying the potential industrial symbiotic opportunities in their hometowns, which is one of the topics for oral presentations. Students come from different regions of China and have a great affection for their hometowns. Through the course, they argued that exploring the potential industrial symbiotic opportunities and establishing eco-industrial parks would be very helpful for their hometowns to realize a harmonious development between the economy and environment. Students who are from rural areas argued that industrial symbiosis needs to be widely applied to agriculture development, which is also promising. In addition, students also enjoyed reflecting on the concept of ecosystem services in the context of their hometowns. As one student from a rural area stated, "Compared with the too much impermeable pavements in cities, most of the land in rural areas can breathe, which helps to provide ecosystem services". Many of the students found that linking with the situation in their hometowns confirms the characteristic of IE that balances theory and practical application. In addition, students are attracted by the group discussion. They stressed that the group composed of members with different backgrounds can enhance the effect of discussion. This observation is similar to the experience described by Cervantes [8].

For sustainability-related teaching, it is essential to acquire affective outcomes such as values, attitudes, motives and social norms [24,25,78,80,86,87]. From students' feedback, it shows that the content including ecosystem services and green infrastructure was appreciated by the majority of the students. They were greatly impressed by the value of ecosystem services. As one student noted, "I never think the natural ecosystem provides so many kinds of services for us and this makes us more deeply and fully recognize the value of nature. Thus we must respect nature and take innovative approaches to protect and 
restore its functions such as through the establishment of green infrastructure." Incorporating these topics into an IE curriculum appears to be novel and helps to change students' value and attitudes toward nature. In addition, it appears that students are enlightened to incorporate IE into their decision making. For example, some students indicated that they will choose models from IE if they have an opportunity to start a business in the future. Some other students argued that IE is helpful to rethink whether the decisions made by governments and companies are reasonable. One student wrote, "this course helps me to transform the way to look at the world and solve the problem. This is also one of the main reasons that I am interested in the course". Thus, it can be seen that the course plays an effective role in achieving outcomes such as changing students' values, attitudes, and behavioral intentions.

Students also provided many valuable suggestions for the course. For example, the majority of the students stated that IE is a very important course and should be compulsory for all of the contemporary college students. This is similar to the viewpoints of some IE educators who argued that IE should be a critical course in universities [10] and introduced to students from every field and discipline at universities [12]. A field trip to an industrial symbiotic project was strongly suggested by many students. This is consistent with some IE educators' teaching experience which indicates that field trips are one of the most interesting experiences for students $[18,20]$ and helps students to combine theory with practice [8]. Shi [20] stressed that field investigations cannot easily be arranged for undergraduate courses due to the limitation of financial support. Therefore, these challenges need to be resolved in order to introduce the field trip in the course in the future. In addition, many students suggested the introduction of more cases into this course. More interestingly, several students recommended to introduce some examples of IE and industrial symbiosis failures. In general, students' suggestions on the course further reveals that students are very interested in the practical application of IE.

\subsection{The Integrated Application of Teaching Strategies}

Considering that the students knew little about IE before participating in the course, lecturing is an essential teaching strategy for introducing factual knowledge to students, such as the concepts and history of IE. However, only adopting lecturing is not effective for IE teaching. Shi [20] stressed that adopting lecturing as the dominant teaching element may not realize the purpose of teaching. In our course, it is found that integrating a wide range of teaching strategies is very helpful and important for teaching IE. For example, when teaching the contents related to industrial symbiosis, the important viewpoint put forward by Cohen-Rosenthal [88], "knowledge of kinds of waste streams can provide a means to determine potential linkages. But this does not link them; decisions by people do." (p. 245) was specifically introduced and explained to students through lecturing. Then students were encouraged to reflect on drivers and barriers for industrial symbiosis based on this viewpoint when conducting case studies and group discussions. Students further felt how the drivers and barriers for industrial symbiosis work and the process that people make decisions on implementing an industrial symbiosis in real world through the role play exercise. Thus, students more deeply understood the meaning of this viewpoint through the combination of these teaching strategies. In particular, it is observed that the role play game can be closely linked with other teaching strategies, such as lectures, case studies and group discussions, which contribute to achieving effective teaching outcomes for our IE course. This confirms the suggestions of McConville et al. [54] that linkages between the role play game and other course elements needs to be strengthened in order to provide more effective learning on sustainability. The ecosystem services and scavenger and decomposer companies, which are both important contents in this course, were also taught to students through a combination of teaching strategies such as lecturing, group discussions, oral presentations, and case studies. Furthermore, the teacher's personal field investigation experience and video clips on some cases were presented to students in class, which was very attractive to them. Integrating these teaching strategies helps students 
understand and see how the measures of protecting and restoring ecosystem services are taken and how wastes or byproducts are used by scavenger and decomposer companies in real-world examples of industrial symbiosis or eco-industrial parks in more detail.

Other teaching strategies are also important for the course. Through the survey at the beginning of the class, the background information on students' understanding on the concept of IE before they select the course can be grasped by teachers. The evaluation aims to comprehensively assess students' understanding on IE and their abilities to apply the knowledge of IE. For this reason, it not only focuses on the final report, but also combines the regular performance, including oral presentation, role playing games and regular homework. This kind of comprehensive evaluation approach is also advocated by other IE educators' experience [10]. Feedback provides opportunities for students to express their feelings on the course and convey this information to teachers, which is helpful to continuously improve the course in the future.

In addition to the feedback we designed in the teaching strategies, the Teaching Affairs Division of BIT also provides an opportunity for students to anonymously evaluate a course after the final exam each semester. All the students passed the course. They are required to evaluate mainly from five aspects: (1) the course can combine theory with practice, (2) the teaching methods can stimulate interest in learning and active learning, (3) the teaching effect, (4) the ability to think independently is improved, (5) the ability to solve some practical problems independently is enhanced. Students are required to choose one from five options provided: excellent, good, fair, acceptable, and poor. The results show that the majority of students chose either "excellent" (around 85\%) or "good" (around 10\%) in all five components of the evaluation. This indicates that the course received highly positive evaluation by the participating students. Our finding confirms the viewpoint of Biswas [12] that adopting different pedagogical strategies helps to enhance student satisfaction for IE education.

From the above analysis, it can be seen that the wide range of teaching strategies adopted in this course effectively integrates the passive method, i.e., lecturing, and active methods such as role playing games, group discussions and case studies. It assists in stimulating students' interests in learning the knowledge of IE, motivating students' active participation in classroom activities and helps students to achieve a combination of theory and practice, especially better feel the practical application of IE in the real world. The integrated teaching strategy adopted in the course has not been found in other IE education literature.

\section{Outlook}

The practice of IE education for undergraduate students at BIT has achieved many results. However, there are still some problems which should be gradually improved in the future.

- A field trip on an industrial symbiosis was suggested by many students. However, field trips often face barriers such as institutional barriers, which leads to increasing difficulty of gaining permission from the university [46]. Many of the students choosing our course are from different majors. Furthermore, BIT requires all of the general education courses to be conducted in the evening. Thus, it is hard to find an appropriate time to arrange a field trip for students. As a result, it will be difficult to achieve a field trip in a short term. As an alternative, more videos and pictures made by teachers when investigating some industrial symbioses can be provided for students in class in order to make them see more of a real industrial symbiosis.

- Many students hope to have more time for the role playing games. This was also observed in experience of teaching sustainability using role play games [54]. The course involves many contents which is not easy to be finished within the 28 lecturing hours. For this reason, in addition to a moderate increase of time for role playing games, students can be encouraged to take more time to prepare for it before class, which assists in increasing efficiency and save time in class. In addition, the role playing games can be improved in order to make students more deeply feel the different roles 
played in implementing IE in reality. For example, students can exchange their roles when engaging role playing games and incorporate debate into this process.

- Currently, we still have not invited guest speakers to present specific topics on IE. Some researchers on IE education believe that guest lectures contribute to strengthening the connection between theory and practice $[6,10,12,19]$. In the future, guest lectures can be scheduled, which helps students further understand the practical application of IE.

- Feedback from students can be extended. Almost all of the students who chose the course are freshmen or sophomores. They will continue their undergraduate study after they received IE education in the university. The feedback can include tracking students' future study, research, or work. Biswas [19] reported that feedback from former postgraduate students who were educated by IE and are now in the workforce has been gathered. Therefore, it will be interesting to see what roles of IE education will play for the students in the future.

\section{Conclusions}

As one of the key topics in the field of IE, IE education should be expanded to undergraduate students from various majors at a whole university level. Given the need for knowing and exchanging the practical experiences of IE teaching, case study articles are especially useful for inspiring and encouraging future teaching efforts of IE, which will facilitate the further development of IE education.

The framework for IE teaching presented in this paper is composed of teaching content and strategies and was adopted to teach IE for undergraduate students with Beijing Institute of Technology as a case study. It is found that the framework can be successfully used in an IE course and has been an effective measure for students to understand the IE concept. The teaching content such as industrial symbiosis, eco-industrial parks and ecosystem services with case studies were appreciated by the majority of the students. The teaching strategies include a wide range of elements combining passive and active learning. This can improve student interest in IE and enhance student satisfaction of IE education. It appears that students are enlightened to think of problems through an interdisciplinary lens and incorporate ecological perspectives into their decision making. Exploring a combination of the course knowledge with situation of students' local situation can further inspire their interest in learning in the course and balancing theory and practical application.

The methodology applied in this paper focuses on descriptive and empirical elements. Future research could introduce evaluation tools to quantitatively assess student learning outcomes from the IE course. This paper is based on a single university although it relied on experiences from elsewhere. It may have limited value for generalization because of the contextual nature in China and one particular university. With more research on IE education appearing in the future, the research results could be compared and generalized. We hope that our research could inspire teachers who are interested in teaching IE around the world to describe their experiences in IE education, which is particularly necessary for our planet to achieve sustainable development.

Author Contributions: C.L. designed the general framework of the research and drafted the paper. R.C. provided comments and revised the paper. Both authors have read and agreed to the published version of the manuscript.

Funding: This research was funded by the National Natural Science Foundation of China (41471458), the Foundation of Beijing Institute of Technology (20151042003), and the Graduate Education Reform Project of Beijing Institute of Technology.

Institutional Review Board Statement: Not applicable.

Informed Consent Statement: Not applicable.

Data Availability Statement: Not applicable.

Acknowledgments: We thank all the students who participated in the IE course. We also thank the anonymous reviewers for their helpful comments and the editors for their work. 
Conflicts of Interest: The authors declare no conflict of interest.

\section{Appendix A}

Table A1. Contents of the IE course for undergraduate students at BIT.

\begin{tabular}{|c|c|c|c|}
\hline Parts & Teaching Hours & Contents & Brief Descriptions of the Contents \\
\hline Part one & 2 & $\begin{array}{l}\text { The resource and } \\
\text { environmental challenges } \\
\text { facing human development }\end{array}$ & $\begin{array}{l}\text { - Current environmental problems in the world } \\
\text { - The problems of resource scarcity and environmental } \\
\text { pollution which restrict China's sustainable development }\end{array}$ \\
\hline Part two & 3 & Ecosystem services & $\begin{array}{l}\text { - } \quad \text { Concept of natural ecosystem and ecosystem services } \\
\text { - } \quad \text { Current state of global ecosystem services, } \\
\text { - } \quad \text { Green infrastructure } \\
\text { - }\end{array}$ \\
\hline Part three & 3 & The evolution of IE & $\begin{array}{l}\text { - Different approaches to environmental management, } \\
\text { - } \quad \text { Definitions and evolution of IE, } \\
\text { - The analogy between ecosystem and industrial ecosystem, } \\
\text { - Relationship between cleaner production, eco-efficiency } \\
\text { and IE }\end{array}$ \\
\hline Part four & 4 & $\begin{array}{l}\text { The basic methods, tools and } \\
\text { techniques of IE }\end{array}$ & $\begin{array}{l}\text { - The concept, framework and application of MFA, LCA } \\
\text { and DFE, } \\
\text { - The concept, framework, principles and roles of extended } \\
\text { producer responsibility, } \\
\text { - Extended producer responsibility policies }\end{array}$ \\
\hline Part five & 6 & $\begin{array}{l}\text { Industrial symbiosis and } \\
\text { eco-industrial parks }\end{array}$ & $\begin{array}{l}\text { - Concept of industrial symbiosis and eco-industrial parks, } \\
\text { - The evolution of Kalundborg industrial symbiosis, } \\
\text { - The drivers and barriers of establishing industrial } \\
\text { - } \quad \text { Pymbiosis, } \\
\text { - Chinciples and practices for eco-industrial park planning, } \\
\text { - China's policies for eco-industrial parks }\end{array}$ \\
\hline Part six & 3 & Circular economy & $\begin{array}{l}\text { - } \quad \text { Concepts and principles of circular economy, } \\
\text { Background, history and practice of China's circular } \\
\text { economy, } \\
\text { - Circular Economy Promotion Law in China, } \\
\text { - } \quad \text { Relationship between IE and circular economy }\end{array}$ \\
\hline Part even & 7 & Case studies & $\begin{array}{l}\text { - Individual firm level: cases of implementing cleaner } \\
\text { production and ecological design, } \\
\text { Industrial park level: cases of Burnside Industrial Park, } \\
\text { Devens eco-industrial park, Tianjin } \\
\text { Economic-Technological Development Area, and the Hai } \\
\text { Hua Industrial Symbiosis } \\
\text { Social level: cases of China's garbage classification, } \\
\text { extended producer responsibility, and green consumption }\end{array}$ \\
\hline
\end{tabular}

\section{References}

1. Cockerill, K. Innovative industrial ecology education can guide us to sustainable paths. In Technological Choices for Sustainability; Sikdar, S.K., Glavič, P., Jain, R., Eds.; Springer: Berlin/Heidelberg, Germany, 2004; pp. 77-90.

2. Anand, C.K.; Bisaillon, V.; Webster, A.; Amor, B. Integration of sustainable development in higher education-A regional initiative in Quebec (Canada). J. Clean. Prod. 2015, 108, 916-923. [CrossRef]

3. Cassen, R.H. Our common future: Report of the world commission on environment and development. Int. Aff. 1987, $64,126$. [CrossRef]

4. Miguel, N.P.; Lage, J.C.; Galindez, A.M. Assessment of the development of professional skills in university students: Sustainability and serious games. Sustainability 2020, 12, 1014. [CrossRef] 
5. Côté, R.P. Exploring the analogy further. J. Ind. Ecol. 2000, 3, 11-12. [CrossRef]

6. Finlayson, A.; Markewitz, K.; Frayret, J.M. Postsecondary education in industrial ecology across the world. J. Ind. Ecol. 2014, 18, 931-941. [CrossRef]

7. Cockerill, K. A failure reveals success: A comparative analysis of environmental education, education for sustainable development, and industrial ecology education. J. Ind. Ecol. 2013, 17, 633-641. [CrossRef]

8. Cervantes, G.A. Methodology for teaching industrial ecology. Int. J. Sustain. High. Educ. 2007, 8, 131-141. [CrossRef]

9. Ning, W.; Chen, P.; Wu, F.; Cockerill, K.; Deng, N. Industrial ecology education at Wuhan University. J. Ind. Ecol. 2007, 11, 147-153. [CrossRef]

10. Geng, Y.; Mitchell, B.; Zhu, Q. Teaching industrial ecology at Dalian University of Technology: Toward improving overall eco-efficiency. J. Ind. Ecol. 2009, 13, 978-989. [CrossRef]

11. Brattebø, H. Industrial ecology and education. J. Ind. Ecol. 2002, 3, 1-2. [CrossRef]

12. Marstrander, R.; Brattebø, H.; Røine, K.; Støren, S. Norway Teaching industrial ecology to graduate students: Experiences at the Norwegian University of Science and Technology. J. Ind. Ecol. 2000, 3, 117-130. [CrossRef]

13. Shi, H.; Moriguichi, Y.; Yang, J. Industrial ecology in China, Part II: Education. J. Ind. Ecol. 2003, 7, 5-8. [CrossRef]

14. Staniskis, J.K.; Stasiskiene, Z. An integrated approach to environmental education and research: A case study. Int. J. Eng. Educ. 2007, 23, 1141-1150. [CrossRef]

15. Goessling-Reisemann, S. Training engineers for sustainability at the University of Bremen. Int. J. Eng. Educ. 2007, 23, 301-308.

16. Matthews, D.H.; Hawkins, T.R.; Jaramillo, P.; Marriott, J.; Sharrard, A.L. The green design apprenticeship. J. Ind. Ecol. 2009, 13, 467-476. [CrossRef]

17. Sharma, A. Interdisciplinary industrial ecology education: Recommendations for an inclusive pedagogical model. Asia Pac. J. Educ. 2009, 29, 75-85. [CrossRef]

18. Eckelman, M.J.; Lifset, R.J.; Yessios, I.; Panko, K. Teaching industrial ecology and environmental management in Second Life. J. Clean. Prod. 2011, 19, 1273-1278. [CrossRef]

19. Biswas, W.K. The importance of industrial ecology in engineering education for sustainable development. Int. J. Sustain. High. Educ. 2012, 13, 119-132. [CrossRef]

20. Shi, L. Industrial ecology education at Tsinghua University. J. Ind. Ecol. 2017, 21, 423-429. [CrossRef]

21. Liu, C.; Côté, R.P. A framework for integrating ecosystem services into China's circular economy: The case of eco-industrial parks. Sustainability 2017, 9, 1510. [CrossRef]

22. The National People's Congress of the People's Republic of China. Circular Economy Promotion Law of the People's Republic of China. Available online: www.lawinfochina.com/display.aspx?id=7025\&lib=law\# (accessed on 5 July 2021).

23. Starr, C. Education for industrial ecology. Proc. Natl. Acad. Sci. USA 1992, 89, 868-869. [CrossRef]

24. Chalkley, B. Education for sustainable development: Continuation. J. Geogr. High. Educ. 2006, 30, 235-236. [CrossRef]

25. Gatti, L.; Ulrich, M.; Seele, P. Education for sustainable development through business simulation games: An exploratory study of sustainability gamification and its effects on students' learning outcomes. J. Clean. Prod. 2019, 207, 667-678. [CrossRef]

26. Perdan, S.; Azapagic, A.; Clift, R. Teaching sustainable development to engineering students. Int. J. Sustain. High. Educ. 2000, 1, 267-279. [CrossRef]

27. Coral, J.S. Engineering Education for a Sustainable Future. Ph.D. Thesis, Universtat Politechnica de Catalunya, Barcelona, Spain, 2009.

28. Sterling, S. Sustainable Education: Re-Visioning Learning and Change. Schumacher Briefings; Green Books: Bristol, UK, 2004.

29. Figueirò, P.S.; Raufflet, E. Sustainability in higher education: A systematic review with focus on management education. J. Clean. Prod. 2015, 106, 22-33. [CrossRef]

30. Barth, M.; Godemann, J.; Rieckmann, M.; Stoltenberg, U. Developing key competencies for sustainable development in higher education. Int. J. Sustain. High. Educ. 2007, 8, 416-430. [CrossRef]

31. Cotton, D.; Baileyb, I.; Warrenb, M.; Bissell, S. Revolutions and second-best solutions: Education for sustainable development in higher education. Stud. High. Educ. 2009, 34, 719-733. [CrossRef]

32. Stubbs, W.; Schapper, J. Two approaches to curriculum development for educating for sustainability and CSR. Int. J. Sustain. High. Educ. 2011, 12, 259-268. [CrossRef]

33. Cotton, D.; Winter, J. 'It's not just bits of paper and light bulbs': A review of sustainability pedagogies and their potential for use in higher education. In Sustainability Education: Perspectives and Practice across Higher Education; Jones, P., Selby, D., Sterling, S., Eds.; Earthscan: London, UK, 2010; pp. 39-54.

34. Christie, B.A.; Miller, K.K.; Cooke, R.; White, J.G. Environmental sustainability in higher education: How do academics teach? Environ. Educ. Res. 2013, 19, 385-414. [CrossRef]

35. Piasentin, F.B.; Roberts, L. What elements in a sustainability course contribute to paradigm change and action competence? A study at Lincoln University, New Zealand. Environ. Educ. Res. 2018, 24, 694-715. [CrossRef]

36. Widener, J.M.; Gliedt, T.; Tziganuk, A. Assessing sustainability teaching and learning in geography education. Int. J. Sustain. High. Educ. 2016, 17, 698-718. [CrossRef]

37. Abd-Elwahed, M.S.; Al-Bahi, A.M. Sustainability awareness in engineering curriculum through a proposed teaching and assessment framework. Int. J. Technol. Des. Educ. 2021, 31, 633-651. [CrossRef] 
38. Cebrián, G.; Mercè, J.; Mulà, I. Competencies in education for sustainable development: Exploring the student teachers' views. Sustainability 2015, 7, 2768-2786. [CrossRef]

39. Exley, K.; Dennick, R. Giving a Lecture: From Presenting to Teaching, 2nd ed.; Routledge: New York, NY, USA, 2009.

40. Azapagic, A.; Perdan, S.; Shallcross, D. How much do engineering students know about sustainable development? The findings of an international survey and possible implications for the engineering curriculum. Eur. J. Eng. Educ. 2005, 30, 1-19. [CrossRef]

41. Bosselmann, K. University and sustainability: Compatible agendas? Educ. Philos. Theory 2001, 33, 167-186. [CrossRef]

42. Mulder, K.F. Engineering curricula in sustainable development: An evaluation of changes at Delft University of Technology. Eur. J. Eng. Educ. 2006, 31, 133-144. [CrossRef]

43. Sprain, L.; Timpson, W.M. Pedagogy for sustainability science: Case-based approaches for interdisciplinary instruction. Environ. Commun. 2012, 6, 532-550. [CrossRef]

44. Prado, A.M.; Arce, R.; Lopez, L.E.; García, J.; Pearson, A.A. Simulations versus case studies: Effectively teaching the premises of sustainable development in the classroom. J. Bus. Ethics 2020, 161, 303-327. [CrossRef]

45. Cortese, A.; Hattan, A.S. Education for sustainability as the mission of higher education. Sustainability 2010, 3, 48-52. [CrossRef]

46. Tziganuk, A.; Gliedt, T. Comparing faculty perceptions of sustainability teaching at two U.S. universities. Int. J. Sustain. High. Educ. 2017, 18, 1191-1211. [CrossRef]

47. Jain, S.; Aggarwal, P.; Sharma, N.; Sharma, P. Fostering sustainability through education, research and practice: A case study of TERI University. J. Clean. Prod. 2013, 61, 20-24. [CrossRef]

48. Cotton, D.R.E.; Warren, M.F.; Maiboroda, O.; Bailey, I. Sustainable development, higher education and pedagogy: A study of lecturers' beliefs and attitudes. Environ. Educ. Res. 2007, 13, 579-597. [CrossRef]

49. Pullen, S.; Brinkert, K. SolEn for a sustainable future: Developing and teaching a multidisciplinary course on solar energy to further sustainable education in chemistry. J. Chem. Educ. 2014, 91, 1569-1573. [CrossRef]

50. Jia, Q.; Wang, Y.; Li, F. Establishing transdisciplinary minor programme as a way to embed sustainable development into higher education system: Case by Tongji University, China. Int. J. Sustain. High. Educ. 2019, 20, 157-169. [CrossRef]

51. Lai, Y.; Peng, L. Effective teaching and activities of excellent teachers for the sustainable development of higher design education. Sustainability 2020, 12, 28. [CrossRef]

52. Dieleman, H.; Huisingh, D. Games by which to learn and teach about sustainable development: Exploring the relevance of games and experiential learning for sustainability. J. Clean. Prod. 2006, 14, 837-847. [CrossRef]

53. Brundiers, K.; Wiek, A.; Redman, C.L. Real-world learning opportunities in sustainability: From classroom into the real-world. Int. J. Sustain. High. Educ. 2010, 11, 308-324. [CrossRef]

54. McConville, J.R.; Rauch, S.; Helgegren, I.; Kain, J. Using role-playing games to broaden engineering education. Int. J. Sustain. High. Educ. 2017, 18, 594-607. [CrossRef]

55. Dlouhá, J.; Burandt, S. Design and evaluation of learning processes in an international sustainability oriented study programme. In search of a new educational quality and assessment method. J. Clean. Prod. 2015, 106, 247-258. [CrossRef]

56. Butler, A.C. Multiple-choice testing in education: Are the best practices for assessment also good for learning? J. Appl. Res. Mem. Cogn. 2018, 7, 323-331. [CrossRef]

57. Carless, D.; Salter, D.; Yang, M.; Lam, J. Developing sustainable feedback practices. Stud. High. Educ. 2011, 36, 395-407. [CrossRef]

58. Semerjian, L.; El-Fadel, M.; Zurayk, R.; Nuwayhid, I. Interdisciplinary approach to environmental education. J. Prof. Issues Eng. Educ. Pract. 2004, 130, 173-181. [CrossRef]

59. Hoare, A.; Cornell, A.; Bertram, C.; Gallagher, K.; Heslop, S.; Lieven, N.; MacLeod, C.; Morgan, J.; Pickering, A.; Wells, S.; et al. Teaching against the grain: Multi-disciplinary teamwork effectively delivers a successful undergraduate unit in sustainable development. Environ. Educ. Res. 2008, 14, 469-481. [CrossRef]

60. Hawkins, T.R.; Matthews, D.H. A classroom simulation to teach economic input-output life cycle assessment. J. Ind. Ecol. 2009, 13, 622-637. [CrossRef]

61. Yuan, Z.; Bi, J.; Moriguichi, Y. The circular economy: A new development strategy in China. J. Ind. Ecol. 2006, 10, 4-7. [CrossRef]

62. Lowitt, P.; Côté, R.P. Putting the eco into eco parks. J. Ind. Ecol. 2013, 17, 343-344. [CrossRef]

63. United Nations (UN). Transforming Our World: The 2030 Agenda for Sustainable Development. Available online: https: / /sdgs.un.org/2030agenda/ (accessed on 17 March 2021).

64. United Nations Environment Programme (UNEP). Green is Gold: The Strategy and Actions of China's Ecological Civilization. 2016. Available online: http:/ / www.indiaenvironmentportal.org.in/files/file/greenisgold.pdf (accessed on 17 March 2019).

65. Frosch, D.; Gallopoulos, N. Strategies for manufacturing. Sci. Am. 1989, 261, 144-152. [CrossRef]

66. Walls, J.L.; Paquin, R.L. Organizational perspectives of industrial symbiosis. Organ. Environ. 2015, 28, 32-53. [CrossRef]

67. United Nations Environment Programme (UNEP). The Environmental Management of Industrial Estates; Industry and Environment Technical Report No. 39; United Nations Publication: Paris, France, 1997.

68. Côté, R.P.; Ellison, R.; Hall, J.G.; Klynstra, P.; Martin, M.; Wade, P. Designing and Operating Industrial Parks as Ecosystems; Technical Report; School for Resource and Environmental Studies, Dalhousie University: Halifax, NS, Canada, 1994.

69. Chertow, M. Industrial symbiosis: Literature and taxonomy. Annu. Rev. Energy Environ. 2000, 25, 313-337. [CrossRef]

70. Côté, R.P.; Hall, J. Industrial parks as ecosystem. J. Clean. Prod. 1995, 3, 41-46. [CrossRef]

71. Liu, C.; Côté, R.P. Controlling chromium slag pollution utilising scavengers: A case of Shandong Province, China. Waste Manag. Res. 2015, 33, 363-369. [CrossRef] 
72. Geng, Y.; Côté, R.P. Scavengers and decomposers in an eco-industrial park. Int. J. Sustain. Dev. World Ecol. 2002, 9, 333-340. [CrossRef]

73. Cossu, R.; Williams, I.D. Urban mining: Concepts, terminology, challenges. Waste Manag. 2015, 45, 1-3. [CrossRef] [PubMed]

74. Zhang, L.M.; Zhong, Y.G.; Geng, Y. A bibliometric and visual study on urban mining. J. Clean. Prod. 2019, 239, 118067. [CrossRef]

75. Ellen MacArthur Foundation. Towards a Circular Economy: Business Rationale for an Accelerated Transition. Available online: https: / / www.ellenmacarthurfoundation.org/assets/downloads/TCE_Ellen-MacArthur-Foundation_9-Dec-2015.pdf (accessed on 22 June 2016).

76. Lozano, R. Diffusion of sustainable development in universities' curricula: An empirical example from Cardiff University. $J$. Clean. Prod. 2010, 18, 637-644. [CrossRef]

77. Graedel, T.E.; Allenby, B.R. Gongye Shengtaixue [Industrial Ecology], 2nd ed.; Shi, H., Translator; Tsinghua University Press: Beijing, China, 2003. (In Chinese)

78. Anderson, M.W.; Teisl, M.F.; Criner, G.K. Attitude changes of undergraduate university students in general education courses. J. Gen. Educ. 2007, 56, 149-168. [CrossRef]

79. Hvenegaard, G. A novel approach to deepen understanding of undergraduates' environmental backgrounds. Int. Res. Geogr. Environ. Educ. 2007, 16, 328-338. [CrossRef]

80. Kuo, S.Y.; Jackson, N.L. Influence of an environmental studies course on attitudes of undergraduates at an engineering university. J. Environ. Educ. 2014, 45, 91-104. [CrossRef]

81. Branson, R. Re-constructing Kalundborg: The reality of bilateral symbiosis and other insights. J. Clean. Prod. 2016, 112, 4344-4352. [CrossRef]

82. Camargo, M.E.; Jacobi, P.; Ducrot, R. Role-playing games for capacity building in water and land management: Some Brazilian experiences. Simul. Gaming 2007, 38, 472-493. [CrossRef]

83. Lowry, P.E. A role-playing simulation course. J. Econ. Educ. 1999, 30, 119-126. [CrossRef]

84. Lean, J.; Moizer, J.; Towler, M.; Abbey, C. Simulations and games: Use and barriers in higher education. Act. Learn. High. Educ. 2006, 7, 227-242. [CrossRef]

85. Duchatelet, D.; Gijbels, D.; Bursens, P.; Donche, V.; Spooren, P. Looking at role-play simulations of political decision-making in higher education through a contextual lens: A state-of-the-art. Educ. Res. Rev. 2019, 27, 126-139. [CrossRef]

86. Sidiropoulos, E. The personal context of student learning for sustainability: Results of a multi-university research study. J. Clean. Prod. 2018, 181, 537-554. [CrossRef]

87. Menon, S.; Suresh, M. Synergizing education, research, campus operations, and community engagements towards sustainability in higher education: A literature review. Int. J. Sustain. High. Educ. 2020, 21, 1015-1051. [CrossRef]

88. Cohen-Rosenthal, E. A walk on the human side of industrial ecology. Am. Behav. Sci. 2000, 44, 245-264. [CrossRef] 